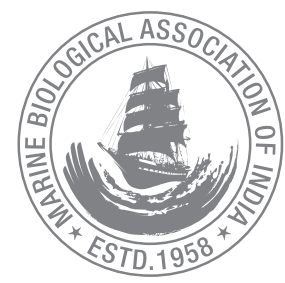

\title{
Seasonal availability and population structure of Eurobowmaniella simulans W. Tattersall, 1915 (Crustacea: Mysida) along Vizhinjam coast, Kerala, India
}

\author{
P. Neethu Raj*, M. K. Anil and M. V. Rohini Krishna \\ Vizhinjam Research Centre of CMFRI, Vizhinjam, Thiruvananthapuram, Kerala-695 521. \\ *Correspondence e-mail: neethurajp08@gmail.com
}

Received: 14 Jan 2016, Accepted: 24 May 2016, Published: 30 May 2016

Original Article

\begin{abstract}
Eurobowmaniella simulans is the commonly available species of mysid along the Vizhinjam coast of Kerala. Sampling of mysids has been carried out over a period of one year from March 2014 to February 2015 to study the seasonal availability and population structure. Monthly samples of mysids consisted of individuals in various developmental stages, from juveniles to mature mysids around the year, but their percentage availability varied. The peak availability of mysids was recorded during September (2014) (avg. 48,731 numbers per haul) and their availability was lowest in July (2014) with an average of 2 individuals per haul. The availability of brooding or ovigerous females were observed throughout the year and highest and lowest percentage availability was during November (2014) and April (2014) respectively. Morphometric measurements of E. simulans revealed that their average size (TL) ranged from $2.35 \pm 0.52 \mathrm{~mm}$ (juvenile) to $7.47 \pm 1.75 \mathrm{~mm}$ (adult). Sex could be first distinguished externally when mysid attains the total length between $4.1 \mathrm{~mm}$ and 5 $\mathrm{mm}$. Analysis of variance of different water quality parameters and mysid density comparing seasons revealed that there was significant variation of mysid availability between seasons $(P<0.05)$. Multivariate Pearson's correlation analysis of water quality parameters and mysid density showed that there was a significant relation with chlorophyll a content $(P<0.001)$ of seawater. The present study also revealed that mysids are available in harvestable quantities for aquaculture purposes from August to November.
\end{abstract}

Keywords: Eurobowmaniella simulans, availability, population structure, developmental stages, Vizhinjam coast

\section{Introduction}

Mysids are small crustaceans and an important zooplankton component in marine and estuarine waters. They show significant variation in their availability in different seasons and they occur in all regions of the oceans. They are grouped under macro-zooplankton since their size range from 1.5 to $25 \mathrm{~mm}$ in total length. They are used as live feed to rear many difficult species which feed exclusively on live feed. Mysids of different size range are found suitable as live-feed in the larval rearing of newly hatched squid and cuttlefish larvae (Domigues et al., 2001; Nabhitabhata, 1996; Anil, 2003), nursery rearing of ornamental fishes, food-fishes and serve as livefeed for many other marine organisms (Beyst et al., 2001), thus acting as a trophic link between primary producers and secondary consumers. Mysids are omnivorous and cannibalistic, feeding on diatoms and small crustaceans such as copepods (Odum and Herald,1972; Mauchline,1980). 
Mysids can be cultured in laboratory by providing Artemia, rotifer, copepod, phytoplankton (Domigues et al., 2000; Lussier et al., 1988; Viherluoto, 2001) and mussel meat suspension (personal observation). Eurobowmaniella simulans is the common species of mysid found along the Vizhinjam coast (Biswas, 2005). Biju (2008) collected this species from the coastal waters of the Arabian Sea during monsoon (JuneSeptember).

Published works on mysid shrimps of southwest coast of Kerala are markedly lacking. Biswas (2005) conducted a short term study on the culture of new live prey organisms with focus on mysids. A number of continually changing environmental factors such as temperature, salinity, dissolved oxygen, suspended particles and currents modify the physiological performance of organisms (Vernberg and Vernberg, 1970). Chlorophyll concentration is regarded as an indicator of phytoplankton abundance and biomass in coastal and estuarine waters (Biju, 2008; Biju et al., 2009). Environmental factors such as temperature, salinity, dissolved oxygen, suspended particles, and currents influence the seasonal availability, abundance and distribution of mysid species (Brandt et al., 1993; Kohn, 1992; DeGreave and Reynolds, 1975; McLusky and Heard, 1979). Laboratory rearing of mysids revealed that they are highly adaptive, and can tolerate a wide range of conditions (Domigues et al., 1999, 2000,2001; Lussier et al., 1988). Mysids can be used as a live feed in aquaculture especially during the months of their swarming. For the captive rearing of cephalopod hatchlings it is of importance to know about the seasonal availability of mysids, as mysids are considered as best live feed for cephalopod larval culture (Anil et al., 2005; Minton et al., 2001). Present study focuses on the seasonal, day time variations in availability and population structure of mysid E. simulans along Vizhinjam coast with special emphasis on effect of environmental parameters on its population density. This paper also elucidates the morphometric and biological features of $E$. simulans briefly.

\section{Material and methods}

The present study was conducted at Vizhinjam coast (Kovalam Light House beach), which is located on the west coast of Kerala, about $12.8 \mathrm{~km}$ south off Thiruvananthapuram at $8^{\circ} 22^{\prime} 56.13^{\prime \prime} \mathrm{N}$ lat and $76^{\circ} 58^{\prime} 51.01$ "E long (Fig. 1). Data was collected fortnightly and pooled to get monthly values, over a period of one year from March 2014 to February 2015.

Various physicochemical parameters were measured using standard techniques. Ammonia level was checked using the phenol hypochlorite method (Solorzano, 1969). Nitrate, nitrite and phosphate were checked using nitrate, nitrite and phosphate testing kits (MERCK) by adopting photometric

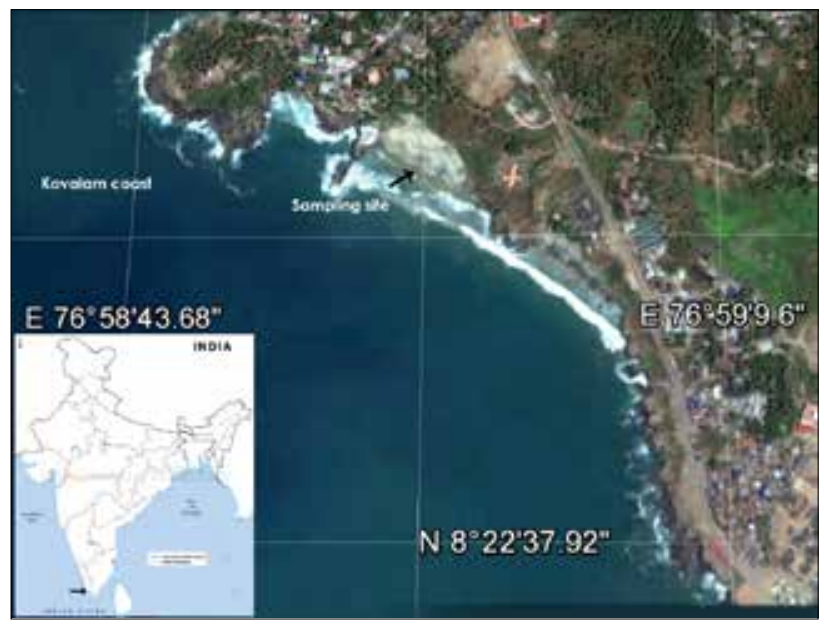

Fig.1. Sampling Site

method (NOVA60, Spectroquent). Temperature (Centigrade thermometer), dissolved oxygen (Winkler, 1888), pH (Compact pH meter, LAQUA twin), and salinity (Master Refractometer, ATAGO) were checked fortnightly. Chlorophyll a concentration was analysed with UV Visible Spectrophotometer (Evolution 201) (Strickland and Parsons, 1972).

Mysids were collected from the intertidal area by hauling a conical plankton net of $50 \mathrm{~cm}$ diameter, with a mesh size of $200 \mu \mathrm{m}$ covering a distance of 50 meters. Samples were sorted out and counted for the number of mysids per haul. Mysids were immediately transferred to plastic buckets filled with sea water taken from the sampling site and brought to the laboratory for further analysis. For morphometric and biological studies samples were preserved in $10 \%$ formalin. Mysids were sorted out and identified under a stereozoom microscope (Leica DFC 295) to find out the structure and composition of population. Individuals were classified into different developmental stages based upon their external appearance, sexual and morphometric characteristics and were grouped according to Tueanta et al., 2012 as, (1) Juvenile; (2) Immature or sub-adult male; (3) Mature male (Fig. 6); (4) Immature or subadult female ; (5) Mature female (Fig. 5); (5a) Brooding or ovigerous female (marsupium with eggs or larvae); and (5b) Empty female (marsupium empty or post-nauplii were hatched out). Monthly percentage availability of mysids of different developmental stages were recorded. Day time variation in mysid availability was recorded by collecting and counting mysids at different times of the day (Morning $7.00 \mathrm{am}$, noon $12.00 \mathrm{pm}$ and evening $5.00 \mathrm{pm}$ ). Observations were made during normal days and cloudy days.

\section{Results}

Water quality parameters recorded from March 2014 to February 2015 are presented in Figs. 2-6. The mean air and 


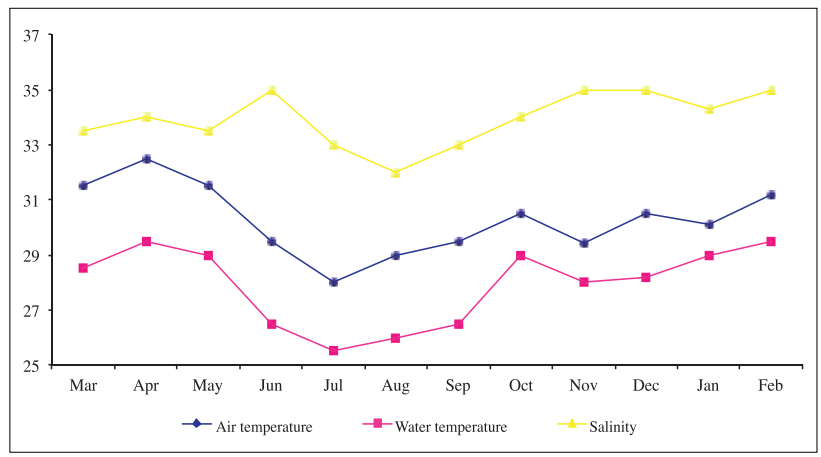

Fig.2. Air and water temperature $\left({ }^{\circ} \mathrm{C}\right)$ and salinity (ppt) during the study period

water temperatures were $30.3 \pm 1.27^{\circ} \mathrm{C}$ and $27.93 \pm 1.43^{\circ} \mathrm{C}$ respectively during the study period. Temperature showed only a slight variation during the sampling period, water temperature ranged between $25.5^{\circ} \mathrm{C}$ in July and $29.5^{\circ} \mathrm{C}$ in February. Air temperature was $28^{\circ} \mathrm{C}$ during July and $31.2^{\circ} \mathrm{C}$ during February and May. Salinity ranged between 32ppt in August and 35ppt during the months of February, November and December. The mean annual salinity was $33.9 \pm 0.98 \mathrm{ppt}$. $\mathrm{pH}$ ranged between 7.7 during July, August and 8.2 during November and December and the annual mean pH was $8.0 \pm 0.17$. Dissolved oxygen ranged between $2.6 \mathrm{mg} / \mathrm{l}$ in July and $6.1 \mathrm{mg} / \mathrm{l}$ in March and the mean annual value of DO was $4.1 \pm 0.79 \mathrm{mg} / \mathrm{l}$.

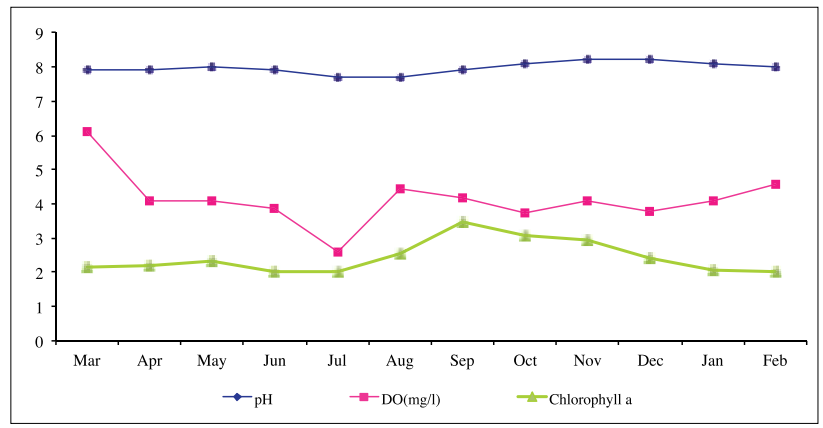

Fig.3. Seasonal values of $\mathrm{pH}$, dissolved oxygen $(\mathrm{mg} / \mathrm{L})$ and Chlorophyll $a$ ( $\mathrm{mg} \mathrm{m}-3$ ) during the study period

The mean concentrations of other parameters recorded were, nitrate $\left(\mathrm{NO}_{3}{ }^{-}\right), 0.058 \pm 0.006 \mathrm{mg} /$; nitrite $\left(\mathrm{NO}_{2}{ }^{-}\right)$, $0.044 \pm 0.009 \mathrm{mg} / \mathrm{l} ;$ ammonia $\left(\mathrm{NH}_{4}+\right), 0.066 \pm 0.021 \mathrm{mg} / \mathrm{l}$; phosphate $\left(\mathrm{PO}_{4}{ }^{-}\right), 0.103 \pm 0.039 \mathrm{mg} / \mathrm{l}$ and showed only slight variations throughout the year. Chlorophyll a values showed significant increase during the last phase of monsoon and initial phase of post monsoon season. The concentration ranged between $2.011 \mathrm{mg} \mathrm{m}^{-3}$ during July to $3.451 \mathrm{mg} \mathrm{m}^{-3}$ during September with an average annual concentration of $2.437 \pm 0.476 \mathrm{mg} \mathrm{m}^{-3}$.

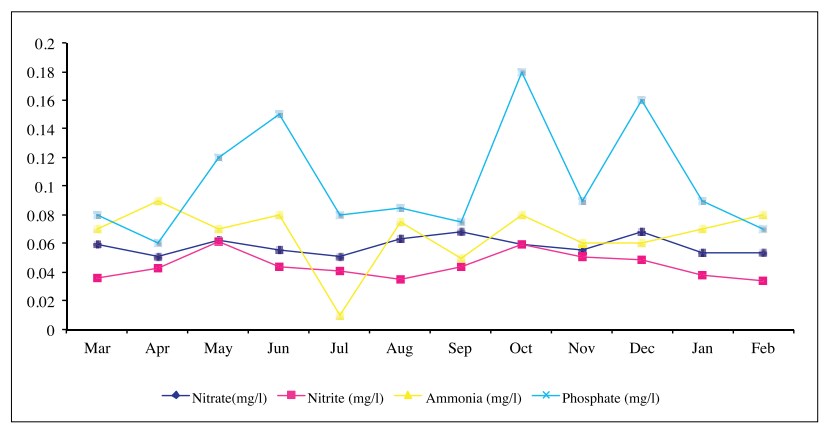

Fig.4. Seasonal variation of Nitrate, Nitrite, Ammonia and Phosphate (mg/L) during the study period

Eurobowmaniella simulans was found to occur along Vizhinjam coast throughout the year in varying intensities. Male and female can be easily distinguished by the presence of brood pouch in females (Fig. 5) and the peculiarity of extended third pleopods and penis in males (Fig. 6). Fertilized eggs develop inside the brood pouch and hatch out as a miniature adult. About 20-35 nauplii (eyed larvae) were recorded in female brood pouch. After the incubation period they are released from the brood pouch as miniature mysids of $1.6-1.8 \mathrm{~mm}$ of total length.

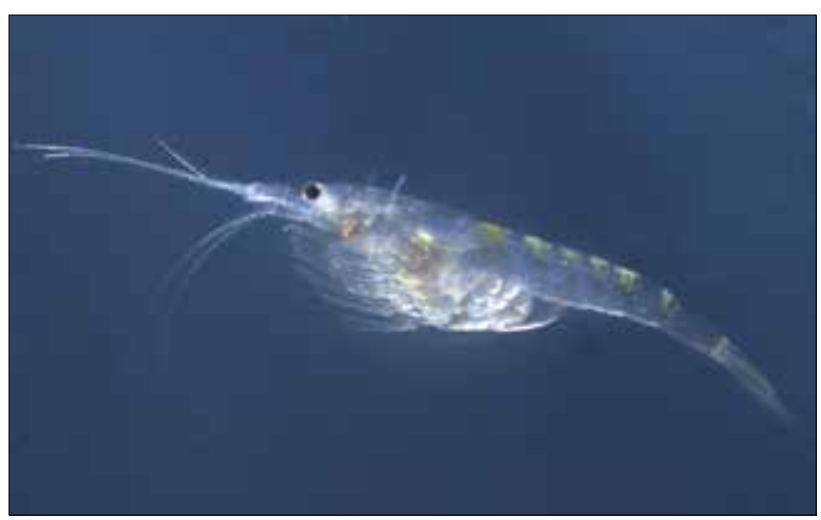

Fig.5. E. simulans, female with brood pouch carrying eggs

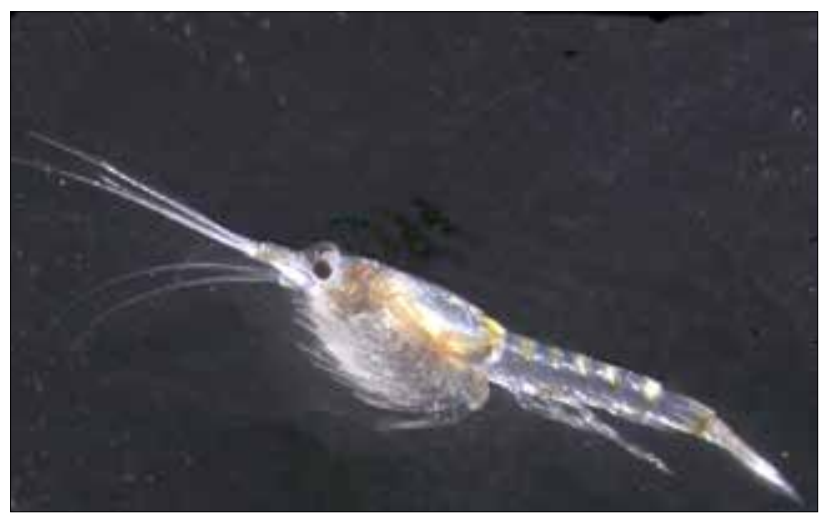

Fig.6. E.simulans male 
The average size ( $\mathrm{TL}$ ) of $E$. simulans ranged between $2.35 \pm 0.52$ $\mathrm{mm}$ (Juvenile) to $7.47 \pm 1.75 \mathrm{~mm}$ (adult). The average total length of mysids at different developmental stages were(1) juvenile (TL-2.35 $\pm 0.52 \mathrm{~mm}$ ); (2) immature or sub-adult male (TL-3.89 $\pm 0.35 \mathrm{~mm}) ;(3)$ mature male (TL- $6.55 \pm 1.68 \mathrm{~mm}) ;(4)$ immature or sub adult female (TL-3.60 $\pm 0.28 \mathrm{~mm}$ ); (5) mature female (TL-7.47 $\pm 1.75 \mathrm{~mm}$ ); (5a) brooding or ovigerous female (TL-7.47 $\pm 1.75 \mathrm{~mm}$ ); and (5b) empty females (TL-6.55 $\pm 2.05 \mathrm{~mm}$ ). Sex could be first distinguished externally when mysid attains the total length between 4.1-5 mm. Females were observed to attain sexual maturity from a total length of $5.7 \mathrm{~mm}$, in males it was from $4.9 \mathrm{~mm}$. Monthly samples of mysids from Vizhinjam coast consisted individuals in all developmental stages, from juveniles to oldest mature mysids, but their percentage availability varied (Fig.8). The peak availability of mysids was recorded during September (avg. 48731 ind. per haul) and least availability was in July with an average number of 2 ind. per haul (Fig.7).

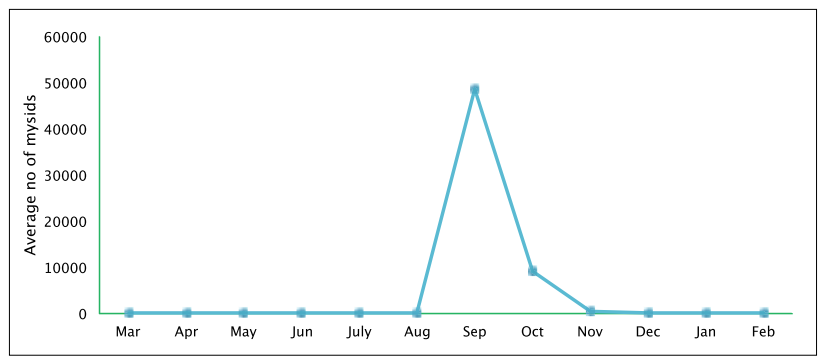

Fig.7. Month-wise distribution of mysids per haul

Mature individuals were observed throughout the study period, peak availability of mature male mysids $(80 \%)$ was recorded in February and peak availability of mature females $(76.67 \%)$ during May. The availability of mature males was lowest during December (10\%) whereas, mature females was lowest $(20 \%)$ during February. The maximum availability of juveniles was recorded during December. Maximum availability of sub-adult males was observed in April (26.7\%). During December, $20 \%$ of sub-adult females were obtained. Mature females consisted of ovigerous or brooding and empty females. The maximum number of ovigerous females were recorded during November $(94.74 \%)$ and minimum number

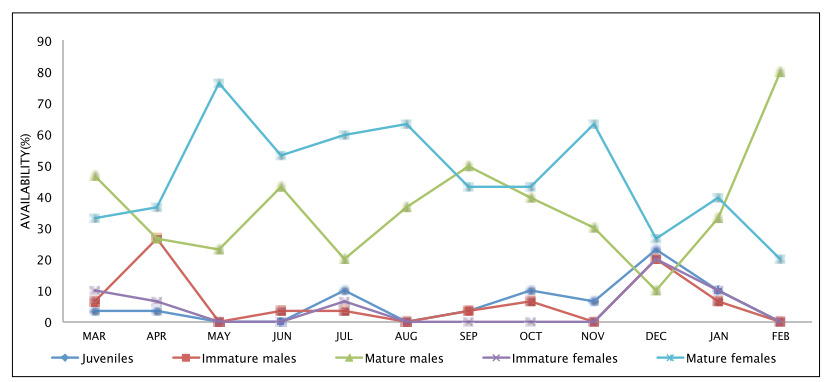

Fig.8. Monthly percentage availability of mysids in different stages

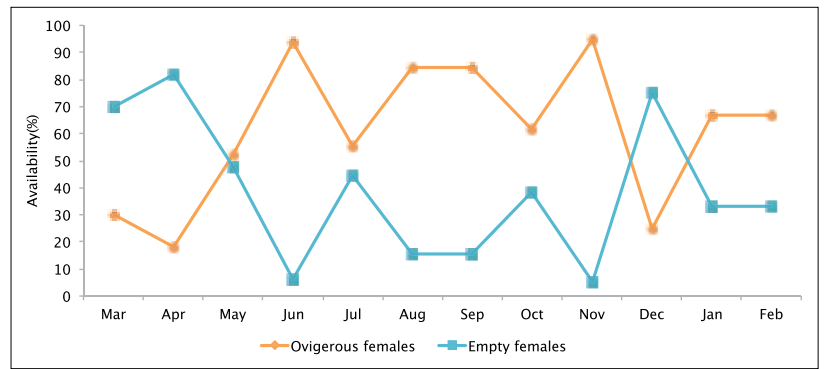

Fig.9. Percentage of ovigerous and empty females during the study period

during April (18.18\%) (Fig. 9).

Availability of mysids during sunny days in the intertidal and surf zones, at different times of the day $(7.00 \mathrm{am}, 12.00 \mathrm{pm}$ and $5.00 \mathrm{pm}$ ) showed significant variations (Fig.10). Number of mysids were maximum during morning hours with an average of $25.55 \pm 21.14$ numbers per haul, minimum during noon with an average of $8.95 \pm 9.02$ numbers per haul since the mysids got buried in sand or moved to deeper waters as the temperature and light intensity increases. Their number was moderate during evening with an average of $16.45 \pm 17.59$ numbers per haul. During cloudy days good collection could be made, even during noon hours ( $23.85 \pm 15.84$ numbers per haul). Low or medium tides were found to be more conducive for mysid collection.

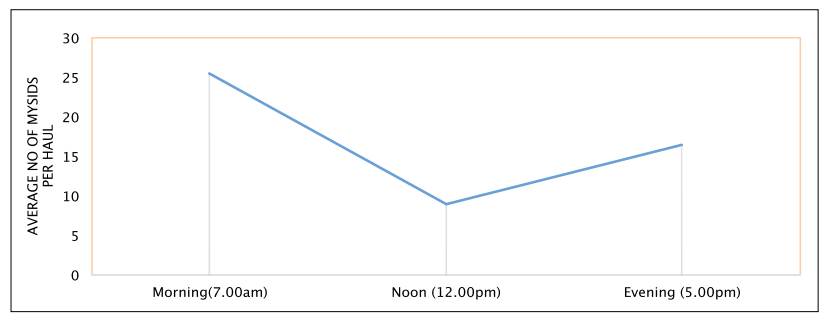

Fig.10. Day time variation in the availability of mysids

Analysis of variance (One Way ANOVA) and Multivariate Pearson's correlation analysis of different water quality parameters and mysid density in various seasons are represented in Table 1 and 2.

\section{Discussion}

The present study unveiled the seasonal availability and population structure of mysid $E$. simulans along Vizhinjam coast. E. simulans can be seen at all times throughout the year but their monthly availability and density varied. ANOVA of different water quality parameters and mysid density against seasons revealed that there was significant variation $(P<0.05)$ of mysid availability between seasons (Table 1). During the pre-monsoon period (February-May) mysids occurred with an average density of $21.2 \pm 16.2$ 
Table 1. Analysis of variance (One Way ANOVA) of different water quality parameters and mysid density comparing seasons.

\begin{tabular}{|c|c|c|c|c|}
\hline Parameter & Season & Mean & $+S D$ & F value \\
\hline \multirow{3}{*}{ Air Temperature } & Pre-monsoon & 31.675 & 0.568 & \multirow{3}{*}{$19.830^{\star \star}$} \\
\hline & Monsoon & 29.000 & 0.707 & \\
\hline & Post-monsoon & 30.125 & 0.519 & \\
\hline \multirow{3}{*}{ Water Temperature } & Pre-monsoon & 29.125 & 0.479 & \multirow{3}{*}{$41.392^{\star \star}$} \\
\hline & Monsoon & 26.125 & 0.479 & \\
\hline & Post-monsoon & 28.550 & 0.526 & \\
\hline \multirow{3}{*}{$\mathrm{pH}$} & Pre-monsoon & 7.950 & 0.058 & \multirow{3}{*}{$18.500^{\star \star}$} \\
\hline & Monsoon & 7.800 & 0.116 & \\
\hline & Post-monsoon & 8.150 & 0.058 & \\
\hline \multirow{3}{*}{ Salinity } & Pre-monsoon & 34.000 & 0.707 & \multirow{3}{*}{2.265} \\
\hline & Monsoon & 33.250 & 1.258 & \\
\hline & Post-monsoon & 34.575 & 0.506 & \\
\hline \multirow{3}{*}{ Dissolved Oxygen } & Pre-monsoon & 4.713 & 0.949 & \multirow{3}{*}{1.905} \\
\hline & Monsoon & 3.770 & 0.813 & \\
\hline & Post-monsoon & 3.933 & 0.195 & \\
\hline \multirow{3}{*}{ Nitrate } & Pre-monsoon & 0.057 & 0.005 & \multirow{3}{*}{0.224} \\
\hline & Monsoon & 0.059 & 0.008 & \\
\hline & Post-monsoon & 0.059 & 0.006 & \\
\hline \multirow{3}{*}{ Nitrite } & Pre-monsoon & 0.044 & 0.012 & \multirow{3}{*}{0.881} \\
\hline & Monsoon & 0.041 & 0.004 & \\
\hline & Post-monsoon & 0.049 & 0.009 & \\
\hline \multirow{3}{*}{ Ammonia } & Pre-monsoon & 0.078 & 0.010 & \multirow{3}{*}{1.415} \\
\hline & Monsoon & 0.054 & 0.032 & \\
\hline & Post-monsoon & 0.068 & 0.010 & \\
\hline \multirow{3}{*}{ Phosphate } & Pre-monsoon & 0.083 & 0.026 & \multirow{3}{*}{1.712} \\
\hline & Monsoon & 0.098 & 0.035 & \\
\hline & Post-monsoon & 0.130 & 0.047 & \\
\hline \multirow{3}{*}{ Chlorophyll a } & Pre-monsoon & 2.176 & 0.128 & \multirow{3}{*}{0.933} \\
\hline & Monsoon & 2.515 & 0.672 & \\
\hline & Post-monsoon & 2.618 & 0.467 & \\
\hline \multirow{3}{*}{ Mysids } & Pre-monsoon & 21.225 & 16.195 & \multirow{3}{*}{$3.045^{*}$} \\
\hline & Monsoon & 12187.000 & 4362.667 & \\
\hline & Post-monsoon & 2382.700 & 509.707 & \\
\hline
\end{tabular}

${ }^{*} \mathrm{P}<0.05 ;{ }^{*} \mathrm{P}<0.001$

Table 2. Multivariate Pearson's correlation analysis of water quality parameters and mysid density.

\begin{tabular}{|c|c|c|c|c|c|c|c|c|c|c|c|}
\hline Parameters & 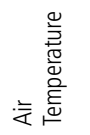 & 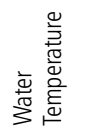 & II & $\begin{array}{l}\text { 謩 } \\
\text { 竘 }\end{array}$ & 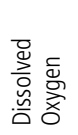 & $\begin{array}{l}\text { 节 } \\
\frac{5}{2}\end{array}$ & 营 & 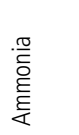 & $\begin{array}{l}\frac{0}{0} \\
\frac{0}{0} \\
\frac{0}{0} \\
\frac{0}{\alpha}\end{array}$ & $\begin{array}{l}\overline{\overline{\bar{\lambda}}} \\
\text { 을 }^{\circ} \\
\text { 흔 }_{\sigma}\end{array}$ & $\frac{\overline{0}}{\bar{n}}$ \\
\hline Air Temperature & 1 & & & & & & & & & & \\
\hline Water Temperature & $0.863^{* *}$ & 1 & & & & & & & & & \\
\hline $\mathrm{pH}$ & 0.321 & $0.633^{*}$ & 1 & & & & & & & & \\
\hline Salinity & 0.279 & 0.501 & $0.754^{\star *}$ & 1 & & & & & & & \\
\hline Dissolved Oxygen & 0.531 & 0.371 & 0.056 & -0.04 & 1 & & & & & & \\
\hline Nitrate & -0.04 & -0.17 & 0.155 & -0.26 & 0.195 & 1 & & & & & \\
\hline Nitrite & 0.139 & 0.231 & 0.491 & 0.178 & -0.34 & 0.255 & 1 & & & & \\
\hline Ammonia & $0.689^{*}$ & $0.627^{*}$ & 0.288 & 0.301 & 0.522 & -0.01 & 0.035 & 1 & & & \\
\hline Phosphate & -0.05 & 0.052 & 0.446 & 0.341 & -0.26 & 0.335 & $0.646^{*}$ & 0.163 & 1 & & \\
\hline Chlorophyll a & -0.2 & -0.15 & 0.237 & -0.21 & -0.04 & $0.585^{\star}$ & 0.435 & -0.06 & 0.173 & 1 & \\
\hline Mysids & -0.18 & -0.27 & -0.08 & -0.3 & -0.02 & 0.522 & 0.077 & -0.21 & -0.11 & $0.751^{\text {** }}$ & 1 \\
\hline
\end{tabular}

${ }^{*} \mathrm{P}<0.05 ;{ }^{*} \mathrm{P}<0.001$ 
ind. per haul, during monsoon (June - September) it was $12187 \pm 4362.7$ ind. per haul and $2382.7 \pm 509.7$ ind. per haul during post-monsoon (October-January). Other parameters which showed significant seasonal variations $(\mathrm{P}<0.001)$ include air temperature, water temperature and $\mathrm{pH}$ (Table 1).

During the last phase of monsoon and post-monsoon seasons a significantly higher availability of this species was recorded, which may be due to nutrient enrichment and subsequent higher primary production in the coastal waters. Multivariate Pearson's correlation analysis (Table 2) of water quality parameters and mysid density showed that there was a significant relation with chlorophyll a content $(\mathrm{P}$ $<0.001)$ of seawater. Chlorophyll concentration is regarded as an indicator of phytoplankton abundance and biomass in coastal and estuarine waters. Biju et al., 2009 reported that chlorophyll values were very high in monsoon period compared to pre-monsoon and post-monsoon periods in Cochin backwaters. A rise in chlorophyll $a\left(3.451 \mathrm{mg} \mathrm{m}^{-3}\right)$ was observed during September, the peak season of mysids. According to Hanamura et al. (2009) food availability is one of the vital factor which regulate the mysid abundance. Pillai (1957) reported the availability of E. simulans along the intertidal areas of Kerala coast during March to October and their peak availability during June and July. Biju (2008) reported that this species was fairly common along the Kerala coast during March to October. The present study showed a peak availability of $E$. simulans during September and October and least availability during July.

According to Kohn (1992), DeGreave and Reynolds (1975) and McLusky and Heard (1979) the distribution, survival and behaviour of mysids were strongly influenced by salinity, temperature and oxygen concentration. Augmented temperature shown to increase the movement and feeding rate of mysids upto a definite limit, after which their mortality starts to increase (DeGreave and Reynolds, 1975; Chipps, 1998). Temperature play an important role in the larval development time in mysids (Mauchline, 1980). Wittman (1981) reported that incubation time is related to water temperature. In the present study a minimum availability was noticed at higher temperatures (noontime during sunny days).

The recorded mean annual pH was $8.0 \pm 0.17, \mathrm{pH}$ above or below the range of tolerance can cause a drastic decline in population density of mysids. Variation in $\mathrm{pH}$ can have major impact on the distribution of organisms (Peter Stiling, 2011). In culture experiments, decrease of $\mathrm{pH}$ is the main reason for the rapid decline of mysid production (Domigues et al. 1998). Only a slight variation of $\mathrm{pH}$ was recorded during the study. The salinity ranged between 32-35 ppt. E. simulans was found to be a euryhaline organism, and comparatively higher abundance of mysids (edge effect) were recorded in certain sites where small streams conjoins with the sea. The effect of salinity on mysid availability and distribution were well documented for some species by Baldo et al. (2001), Bhattacharya (1982), Bhattacharya and Kewalremani (1972), Biju and Panampunnayil (2010) in their studies. Bhattacharya (1982) opined that the mysid, Mesopodopsis orientalis can tolerate from near freshwater condition to $60 \mathrm{ppt}$. salinity if the animals are properly acclimatized.

Biju (2008) reported that the amount of dissolved oxygen in natural water depends up on temperature, salinity, turbulence of water and atmospheric pressure and the low oxygen may also be the result of decomposition of organic matter present in the bottom. Concentration of oxygen was found to play significant influence on the survival, distribution and behaviour of mysids, they seem to avoid areas where oxygen concentration is low (Ackefors, 1969; Salemaa et al., 1986). Low concentration of DO is also an indication of nutrient richness. Johannassen and Dahl (1996) have reported a decline in dissolved oxygen as a result of increased nutrient load. DO did not show significant variations throughout the study period and the mean annual concentration of DO was $4.1 \pm 0.79$ $\mathrm{mg} / \mathrm{l}$. Low oxygen concentration was recorded during the month of July and in the same month lowest availability of mysids was recorded; which may be due to the migration of mysids away from the oxygen deficient areas. Low oxygen in surface waters is a phenomenon associated with upwelling during the south west monsoon period along the south west coast of India.

During the present study, nitrate, nitrite, ammonia and phosphate showed only slight variations and did not show much influence on availability of mysids. According to Brandt et al. (1993) high concentration of ammonia, nitrate, phosphate together with low dissolved oxygen decrease mysid availability. Biju and Panampunnayil (2010) reported a higher productivity in Cochin backwaters during monsoon due to nitrogenous input due to monsoon river flow and a subsequent variation in abundance and distribution of mysid Mesopodopsis zeylanica. Spotte (1979) proposed that the limits for nitrogenous waste levels for most marine animals should follow: $<0.10 \mathrm{mg} / \mathrm{l}$ ammonia, $<0.10 \mathrm{mg} / \mathrm{l}$ nitrite and $<20.00 \mathrm{mg} / \mathrm{l}$ nitrate. The tolerance limits for some species were above these values (Boletzky and Hanlon,1983).

The effect of temperature, $\mathrm{pH}$, salinity, nitrite, nitrate, 
ammonia, phosphate and dissolved oxygen did not show significant correlation with mysid availability in the present study as compared to previous studies which may be due to the insignificant variations in the above parameters during the study period.

During sunny days, the availability of mysids was maximum at morning hours, minimum at noon and their number was moderate at evening. During cloudy days with weak light and temperature a large number of mysids were collected even during noon hours. Mauchline (1980) studied the influence of light on distribution and behavior of mysids. In general mysids are attracted to weak sources of light but avoid bright light. Bright light often inhibits the swimming activity (Mauchline, 1980) and swarming behavior (Steven, 1961). This may be the reason for their low availability at noon during sunny days. In Vizhinjam waters, the study of seasonal availability of $E$. simulans revealed seasonal variations during the study period. Throughout the year the mysid population consisted of individuals in all developmental stages (different age groups), which indicate its reproduction throughout the year. Availability of mysid varied at different times of the day, which was found to be due to the influence of varying intensity of light and temperature. The present study also revealed that mysids are available in harvestable quantities for aquaculture purposes from August to November along Vizhinjam coast.

\section{Acknowledgements}

We gratefully acknowledge the research grants from the Kerala State Council for Science Technology and Environment for carrying out the work. We extend our gratitude to Dr. A. Gopalakrishnan, Director, Central Marine Fisheries Research Institute, Kochi, for the permission granted and facilities provided. We also thank Dr. Rani Mary George, Former Scientist In Charge, Vizhinjam Research Centre of CMFRI for the support provided during the work. We thank Dr. Biju. A, Assistant Professor, PG and Research Department of Zoology, St. Stephen's College, Pathanapuram for the help in identifying samples related to work and Dr. Kurian Mathew Abraham, Associate Professor, PG and Research Department of Zoology, Mar Thoma College, Thiruvalla for help in statistical analysis of data. We also thank all the staff members of Vizhinjam Research Centre of CMFRI for all the support in carrying out the work.

\section{References}

Ackefors, H. 1969. Ecological zooplankton investigations on the Baltic proper 19631965. Series Biology, Institute of marine research, Lysekil, Sweden. No.18:1-139.

Anil, M. K. 2003. Laboratory rearing and breeding of spineless cuttlefish Sepiella inermis, Orbigny (Mollusca: Cephalopoda). J. Aqua. Trop., 18 (1): 35-44.

Anil, M. K., Joseph Andrews and C. Unnikrishnan. 2005. Growth, behavior, and mating of pharaoh Cuttlefish (Sepia pharaonis, Ehrenberg) in captivity, ISR. J. AquacultBamid., 57(1):25-31.

Baldo, F., L. J. Taracido, A. M. Arias and P. Drake. 2001. Distribution and life history of the mysid Rhopalophthalmus mediterraneus in the Guadalquivir estuary (SW Spain). J. Crust. Biol., 21:961-972.

Beyst, B., D. Buysse, A. Dewicke and J. Mees. 2001. Surf zone hyperbenthos of Belgian sandy beaches: seasonal patterns. Estuar. Coast. Shelf Sci., 53:877-895.

Bhattacharya, S. S. and H. G. Kewalremani. 1972. Salinity and temperature tolerance of the mysid Mesopodopsis orientalis from west coast of India. J. Indian. Fish. Ass., 2: 60-68.

Bhattacharya, S. S. 1982. Salinity and temperature tolerance of juvenile Mesopodopsis orientalis: laboratory studies. Hydrobiologia, 93:23-30.

Biju, A. 2008. Studies on taxonomy and ecology of Mysidacea from the EEZ of India. $\mathrm{PhD}$ thesis, Cochin University of Science and Technology.

Biju, A., R. Gireesh, K. J. Jayalakshmi, C. K. Haridevi and S. U. Panampunnayil.2009. Seasonal abundance, ecology, reproductive biology and biochemical composition of Mesopodopsis orientalis W. M. Tattersall (Mysida) from a tropical estuary (Cochin backwater) in India. Crustaceana, 82: 981-996.

Biju, A. and S. U. Panampunnayil. 2010. Seasonality, reproductive biology and ecology of Mesopodopsis zeylanica (Crustacea:Mysida) from a tropical estuary (Cochin backwater) in India. Plankt. Benthos. Res., 5: 49-55.

Biswas, S. 2005. Culture of new live prey organisms with focus on mysids, MFSc Dissertation, Centre Institute of Fisheries Education, Mumbai.

Boletzky, S. V. and R. T. Hanlon. 1983. A review of the laboratory maintenance, rearing and culture of cephalopod molluscs. Mem. Natl. Mus. Vict., 44:147-187.

Brandt, Fujimura and Finlayson. 1993. Use of Neomysis mercedis (Crustacea: Mysidacea) for estuarine toxicity test. Trans. Am. Fish. Soc., 122: 279-288.

Chipps, S. R.1998. Temperature dependent consumption and gut-residence time in the opossum shrimp Mysis relicta. J. Plankton Res., 20:2401-2411.

DeGreave, G. M. and J. B. Reynolds. 1975. Feeding behavior, temperature and light tolerance of Mysis relicta in the laboratory. Trans. Am. Fisheries Soc., 2:394-397

Domingeus, P. M., P. E. Turk., J. P. Andrade and P. G. Lee. 1998. Pilot scale production of mysid shrimp in a static water system. Aquac. Int., 6: 387-402.

Domingues, P. M., P. E. Turk., J. P. Andrade and P. G. Lee. 2001. Effect of different food items on the culture of mysid shrimp Mysidopsis almyra (Crustacea:Pericaridea) in a static water system. Aquac. Int., 9: 393-400, Klawer academic publishers.

Domingues, P. M., P. E. Turk., J. P. Andrade and P. G. Lee. 1999. Culture of the mysid, Mysidopsis almyra (Bowman), (Crustacea:Mysidacea) in static water system: effects of density and temperature on production, survival and growth. Aquacult. Res., 30:1-9.

Domingues, P. M., P. E. Turk., J. P. Andrade and P.G. Lee. 2000. Mysidculture: lowering costs with alternative diets. Aquacult. Res., 31:719-728.

Hanamura, Y., R. Siow., P. E. Chee and M. K. Faizul. 2009. Seasonality and biological characteristics of the shallow-water mysid Mesopodopsis orientalis (Crustacea: Mysida) on a tropical sandy beach, Malaysia. Plankt. Benthos Res., 4: 53-61.

Jaruwat Nabhitabhata.1996. Life cycle of cultured big fin squid, Sepioteuthis lessoniana Lesson, Rayong coastal aquaculture station, TaPong, Rayong province-21000, Thailand, Phuket Mar. Bio. Cen. Spl. Publ. no.16:83-95.

Johannassen and T. E. Dahl. 1996. Decline in oxygen concentration along the Norvegion Skagarrak coast 1927-1993: A signal of ecosystem changes due to eutrophication. Limnol. Oceanogr., 41 (4): 766-778.

Kohn, J. 1992. Mysidacea of the Baltic sea - state of the art. - In: V. J. Köhn, M. B. Jones \& A. M. Moffat (eds.), taxonomy, biology and ecology of (baltic) mysids (Mysidacea: Crustacea), pp. 5-24. International expert conference, Hiddensee, Germany, Rostock university press, Rostock.

Lussier, S. M., A. H. Kuhn., M. J. Chammas and J. Sewall. 1988. Techniques for the laboratory culture of Mysidopsis species (Crustacea: Mysidacea), Environ. Toxicol. chem., 7:969-977.

Mauchline, J. 1980. The biology of Mysids and Euphasids. Part 1. The biology of mysids. In: Advances in Marine Biology (ed. J. H. S. Blaxter, F. S. Russel and C. M. Yonge) Academic Press, London, UK, 18: 1-369.

McLusky, D. S. and V. E. Heard. 1979. Some effect of salinity and Temperature on the osmotic and ionic regulation of mysid Praunus flexous (Crustacea: Mysidacea) Isefjord. Ophelia, 18: 191-203.

Minton, J. W., L. S. Walsh., P. G. Lee and J. W. Forsythe.2001. First multi-generation culture of the tropical cuttlefish Sepia pharaonis Ehrenberg, 1831, Aquac. Int., 9: 375-392, Kluwer Academic Publishers.

Odum, W. E and E. J. Herald. 1972. Trophic analysis an estuarine mangrove community. Bull. Mar. Sci. Gulf and Caribbean, 22:671-738.

Peter Stiling. 2011. Ecology Global Insights and Investigations, McGraw Hill publication, 123-137.

Pillai, N. K. 1957. Pelagic crustacean of travencore II. Schizopoda Bull. Centr. Res. Inst. Univ. Travencore, 5:1-28.

Salemaa, H., K. Tyystjarvi and E. Aro.1986. Life histories, distribution and abundance of Mysis mixta and Mysis relicta in the Northern Baltic Sea. Ophelia Suppl., 4:239-247. 
Solorzano, L. 1969. Determination of ammonia in natural waters by the phenol hypochlorite method. Limnol. Oceanogr., 14:799-801.

Spotte, S. 1979. Fish and invertebrate culture: water management in closed systems. 2nd Edition, Wiley-Interscience, New York, 179 pp.

Steven, D. M. 1961. Shoaling behaviuor of a mysid. Nature, 192:280-281.

Strictland, J. D. H. and T. R. Parsons.1972. A handbook of sea water analysis. Second (ed.), Fish. Res. Bd. Canada, $311 \mathrm{pp}$.

Tattersall, W. M. 1936. Mysidacea and Euphasiacea. Great Barrier Reef Expedition 1928-29, Scientific Reports, 5: 143-176.

Tueanta Ramarn, Ving-Ching Chong and Yukio Hanamura. 2012. Population Structure and Reproduction of the Mysid Shrimp Acanthomysis thailandica (Crustacea:
Mysidae) in a Tropical Mangrove Estuary, Malaysia, Zool. Stud. 51(6): 768-782. Vernberg, F. J. and W. B, Vernberg.1970. The animal and the environment. Holt. Rinehart \& Winston. Inc. Newyork.

Viherluoto, M. 2001. Food selection and feeding behaviour of Baltic Sea mysid shrimps. Sci. Rep, W \& A. de Nottbeck Foundation. 23: 1-35.

Winkler, L.W. 1888. Die Bestimmung des im Wasser gelösten Sauerstoffes. Ber. Dtsch. Chem. Ges., 21:2843-2855.

Wittmann, K. J. 1981.Comparative biology and morphology of marsupial development in Leptomysis and other Mediterranean Mysidacea (crustacea). J. Exp. Mar. Biol. Ecol., 52: 243-270, Elsevier/North-Holland Biomedical Press. 